\title{
Girindra Sekhar Bose : A forgotten genius of psychoanalysis in India
}

\author{
Dr Arabinda Brahma
}

Consultant Psychiatrist, Girindrasekhar Clinic, Kolkata 700009

Hony Lecturer, Indian Psychoanalytical Society, Kolkata

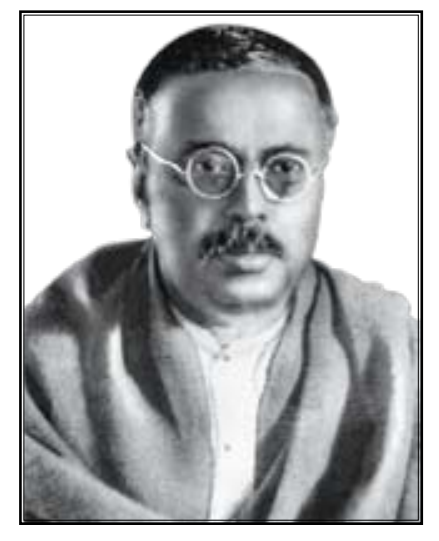

\section{Girindra Sekhar Bose}

Professor Girindrasekhar Bose, D. Sc., M.B., F.N.L., was born on 30th January, 1887 in Darbhanga district of Bihar. The Bose family had the reputation of rich cultural excellence. Girindrasekhar's father Sri Chandrasekhar Bose was the then Dewan of the Darbhanga Raj Estate. One of his brothers, Sri Rajsekhar Bose, was a famous writer of Bengali literature. Girindrasekhar was the youngest of the four sons and five daughters. Since childhood, amiable in his behaviour and inquisitive by nature, he was very much liked by his teachers and peer group.

The academic career of Girindrasekhar was brilliant. He stood first in the first class in B. Sc examination from Presidency College of Calcutta University in 1905 with record marks in Chemistry honours. After that, he passed MB examination from Calcutta Medical College in 1910. Then he got special permission for appearing in the M.Sc. examination from the University of Calcutta in Experimental Psychiatry in 1917 and stood first in the first class.
Just after passing the M.Sc in Psychology, he joined Calcutta University as a part time lecturer in the department of Abnormal Psychology and twelve years later he took up the charge of the department following the persuasion of Dr Sarvapally Radhakrishnan, who was the then President of higher studies.

In 1921, Girindrasekhar was honoured with D, Sc in Psychology from Calcutta University (first of its kind in the University) for his original psychoanalytical research work on "The Concept of Repression". Since then he had academic letter exchange with the then stalwart in western psychoanalysis Sigmund Freud (Bose-Freud Correspondence : 1921-1937) which clearly showed the frank acceptance of Sigmund Freud about the originality of Girindrasekhar's thoughts and analysis. Girindrasekhar's views were original and differed in many aspects from those of Freud. His concept of repression is known as the theory of opposite wishes, which substantially differs from Freudian concept of repression. He also differed from Freud in the importance of castration complex in the resolution of Oedipus complex. 
He did not find castration complex playing that important role especially among Indian patients. In his article "A New Theory of Mental Life", he emphasized on a theoretical ego instead of Freud's tripartite division of mind into Id, Ego and Superego and proposed that many theoretical problems of psychoanalysis can be solved with his theory of opposite wishes and theoretical ego.

Girindrasekhar was not only an eminent psychiatrist and psychologist, but also the father of psychoanalysis in India. He started the Indian Psychoanalytical Society at 14, Parsi Bagan Lane, Kolkata in his own residence in 1922. Of the fifteen original members, nine were college teachers of psychology or philosophy and five belonged to the medical corps of the Indian Army, including two British psychiatrists. One of them was Owen A.R. Berkeley Hill, famous for his work at the Ranchi Mental Hospital. In the same year, Girindrasekhar wrote to Freud in Vienna. Freud was pleased that his ideas had spread to such a far-off land and asked him to write to Ernest Jones, the then President of the International Psychoanalytic Association, for membership of that body. He did so and the Indian Psychoanalytic Society, with Girindrasekhar as president (held the position until his death in 1953) became a member of the international psychoanalytic community. He was also involved in establishing other organisations viz. Indian Association for Mental Health (1928), Indian Psychoanalytical Institute (1936) which clearly shows his innovative ideas in this field.

Girindrasekhar persuaded the authority of Carmichael Medical College (now RG Kar Medical College, Kolkata) to start a Psychiatry Outdoor Clinic in 1933, which was also the first of its kind in the whole of Asia. Later, he started a nongovernment mental hospital in Kolkata with just 3 beds, known as 'Lumbini Park Mental Hospital' in 1940. The property of Lumbini Park Hospital was a donation from his elder brother Sri Rajsekhar
Bose. Very quickly the hospital turned into an 80 bedded indoor facility and became a platform for research work and practical training for young psychiatrists, psychologists and psychoanalysts. However, because of financial constraints and other infra-structural difficulties, it was handed over to the Government of West Bengal in 1970.

Girindrasekhar was actively involved in setting up a training school (Bodhayana) in 1949 for educating normal and abnormal children following psychoanalytic principles. A residential home (Bodhipith) for the children with mental retardation was also established in this connection in 1951.

Being the first student of psychology in India, he was committed to build a strong foundation of psychology in India and world at large. During his leadership in the Psychology department of Calcutta University there were several new approaches, viz. modernisation of post graduate syllabus of psychology, introduction of psychology as a subject at undergraduate level, making psychology as a subject of study in faculty of science at University of Calcutta, introduction of Ph. D programme in psychology etc. In the revision of Post graduate syllabus, he introduced one elective paper. Newer branches of Psychology, e.g. Educational Psychology, Industrial Psychology, Social Psychology and Indian Psychology came through this route. Furthermore, Applied Psychology department would not have gained a footing in Calcutta University without active support of Girindrasekhar Bose.

Over a period of thirty years (1917-1949), Girindrasekhar had a galaxy of students who helped him to spread the 'Psychology Movement in India' by starting psychology departments in different colleges and universities to teach psychology both at undergraduate and post graduate levels. 
Girindrasekhar alsospent many hours in the laboratory to devise apparatus and conduct research. Sand-Motor and Exposure apparatus, Big Muscle Ergo Graph, Group Pass along test, Group Matching test and Dotting test are few examples of his innovative ideas only.

After a prolonged suffering, this great personality died on 3rdJune, 1953 at Kolkata.

In his memory, Indian Psychoanalytical Society started 'Girindrasekhar Clinic' at 14, Parshibagan Lane, Kolkata in 1970 to provide psychiatric and psychoanalytical services to mentally ill persons at a moderate cost. The society also organises different clinical and academic seminars and conferences on a regular basis.Currently the Indian Psychoanalytical Society, Kolkata offers regular training in psychoanalysis and runs a psychiatric counseling course.
Girindrasekhar Bose workedrelentlessly through out his life to upgrade the treatment modalities for the mentally ill patients. It is high time to renew a fresh research initiative on the life and work of DrGirindrasekhar Bose to highlight his original thinking in psychoanalysis for the welfare of millions of mental health clients.

\section{REFERENCES}

1. Dev M. Girindrasekhar Bose's glowing brilliance in the realm of psychology. Psychologic Research J 2003; 27 (1\&2)

2. Mallik A. Bose - Theforgotten genius in psychology. Bengal J Psychiatry 2008; 15 (1)

3. Brahma A. Girindrasekhar Bose - a versatile genius. Bengal J Private Psychiatry 2011; 3 (1)

4. Brahma A \&Bandhopadhyay G. Girindrasekhar Bose and psychiatric education. In : Psychiatry in India : Training \& Training Centres, Indian J Psychiatry (suppl.) 2015 